\title{
Обгрунтування доцільності двохетапного хірургічного лікування морбідного ожиріння
}

\author{
О. Ю. Іоффе, М. С. Кривопустов, Ю. П. Цюра
}

Національний медичний університет імені О. О. Богомольця, м. Київ

\section{Substantiation of expediency of a two-staged surgical treatment of morbid obesity}

\author{
O. Yu. Ioffe, M. S. Kryvopustov, Yu. P. Tsiura \\ Bogomolets National Medical University, Kyiv
}

\section{Реферат}

Мета. Обгрунтувати доцільність двохетапного хірургічного лікування морбідного ожиріння (МО) з використанням внутрішньошлункового балона (ВШБ) як першого етапу.

Матеріали і методи. Обстежено та проліковано 97 пацієнтів з МО, а саме з суперожирінням та високим операційноанестезіологічним ризиком (III-IV клас за шкалою ASA PS - American Society of Anaesthesiologists Physical Status Classification System 2014). Хворих лікували в два етапи. Як перший етап використовували встановлення ВШБ на 6 міс (основна група, $\mathrm{n}=60)$ та консервативну терапію впродовж 6 міс, яка включала дієту, фізичну активність та поведінкове консультування (контрольна група, $\mathrm{n}=37$ ). На другому етапі хворим обох груп проводили хірургічне лікування МO.

Результати. Середній відсоток втрати надлишкової маси тіла (\%EWL - excess weight loss) у хворих основної групи становив 22,69 \$ 5,87 та статистично значуще ( $<$ < 0,001) перевищував зазначений показник у хворих контрольної групи. Рiвень операційно-анестезіологічного ризику за шкалою ASA PS у хворих основної групи статистично значущо (р<0,001) зменшився, що було підставою для проведення саме цим пацієнтам другого етапу лікування МО. Аналіз ефективності лікування, яке включало два етапи, показав, що у цих хворих маса тіла зменшилась у середньому на $(83,31 \pm 16,15)$ кг (мінімально - на 43 кг, максимально - на 113 кг), \%EWL в кінці повного курсу двохетапного лікування становив у середньому 65,28 \pm 6,65 (мінімальний - 53,61, максимальний - 80,49).

Висновки. Обгрунтована доцільність двохетапного лікування хворих з МО та високим операційно-анестезіологічним ризиком: як перший етап - встановлення ВШБ, другий етап - виконання баріатричної операції. Якщо шляхом використання ВШБ досягнуто показників \%EWL, які дорівнюють або перевищують 20, перевагу слід надавати рестриктивним типам баріатричних операцій, менше 20 - шунтуючому баріатричному втручанню; за наявності у пацієнта 3 MO цукрового діабету (ЦД) 2-го типу, незалежно від показників \%EWL, перевагу необхідно надавати шунтуючому баріатричному втручанню.

Ключові слова: морбідне ожиріння; двохетапне хірургічне лікування; операційно-анестезіологічний ризик.

Abstract

Objective. To substantiate the expediency of a two-staged surgical treatment of morbid obesity (MO), using intragastric balloon (IGB) as a first stage.

Materials and methods. There were examined and treated 97 patients, suffering MO (superobesity) and high operative-anesthesiological risk (Class III-IV in accordance to ASA PS - American Society of Anesthesiologists Physical Status Classification System 2014) scale. The patients were treated in two stages: at the first one IGB was introduced endoscopically for 6 mo (main group, $n=60$ ) and conservative therapy - during 6 mo, including diet, physical activity and behavioral consulting (control group, $\mathrm{n}=37$ ). On the second stage to patients of both groups a surgical treatment for MO was conducted.

Results. The average percent of excess weight loss (\%EWL) in the main group of patients have constituted $22.69 \pm 5.87$ and statistically significantly $(\mathrm{p}<0.001)$ have exceeded the index in patients of a control group. The level of operative-anesthesiological risk in accordance to ASA PS scale in the main group of patients have reduced statistically significantly $(p<0.001)$, what served an indication for conduction of a second stage for the MO treatment in these patients. Analysis of the treatment efficacy, consisting of two stages, have shown, that in these patients a body mass have reduced at average by $(83.31 \pm 16.15) \mathrm{kg}(\mathrm{min}-$ imally - by $43 \mathrm{~kg}$, maximally - by $113 \mathrm{~kg}$ ), \%EWL at the end of complete course of a two-staged treatment have constituted at average 65.28 \pm 6.65 (minimal - 53.61, maximal - 80.49).

Conclusion. Expediency of a two-staged treatment in patients with MO and high operative-anesthesiological risk was established: the IGB introduction in a first stage, and in a second one - performance of bariatric operation. If the IGB application have permitted to achieve the \%EWL indices, which equals or exceeds 20 , advantage must be given to restrictive types of bariatric operations, and while lesser than 20 - shunting bariatric intervention; while presence in patient with MO coexistent diabetes mellitus Type II, not depending from the \%EWL indices, the advantage should be given to shunting bariatric intervention. Keywords: morbid obesity; two-staged surgical treatment; operative-anesthesiological risk.

За даними ВООЗ станом на 2016 рік у світі 39\% дорослих мали надлишкову масу тіла, а 13\% страждали від ожиріння [1]. В Україні надлишкову масу тіла мають 58,4\% населення (61,4\% чоловіків та 55,5\% жінок), ожиріння - 24,1\% (22\% чоловіків та 25,7\% жінок) [2]. Міжнародна федера- ція хірургії ожиріння і метаболічних розладів (IFSO) особливу увагу, з огляду на відомі ризики для здоров'я пацієнта, приділяє проблемі МО, тобто ожирінню з індексом маси тіла (IMT) більше 40 кг $/ \mathrm{M}^{2}$, окремо виділяючи суперожиріння (IMT більше 50 кг $/ \mathrm{M}^{2}$ ) [3]. Ожиріння є причи- 
ною підвищеної захворюваності, інвалідності, смертності і зниження якості життя (рівень доказовості 1 за Scottish Intercollegiate Guidelines Network, 2010) [4].

Відомо, що причини ожиріння мультифакторіальні, отже, і вирішення цієї проблеми має бути мультидисциплінарним [5]. При цьому розглядають модифікацію способу життя, що включає дієту, фізичну активність, поведінкове консультування тощо. Однак недостатня ефективність консервативних методів лікування ожиріння зумовлює необхідність впровадження в клінічну практику баріатричних операцій [6].

Показаннями до хірургічного лікування ожиріння за AACE/TOS/ASMBS Guidelines (2013) є IMT, який дорівнює або перевищує 40 кг/м² без коморбідних медичних проблем, IMT, який дорівнює або перевищує 35 кг/м² з одним чи більше тяжким, пов'язаним з ожирінням, супутнім захворюванням. Можливість виконання зазначених втручань у пацієнтів з ЦД 2-го типу або метаболічним синдромом та IMT 30 - 34,9 кг/м² дискутується [6].

Однак існує проблема операційно-анестезіологічного ризику у пацієнтів з МО, особливо з суперожирінням [7].

Мета дослідження: обгрунтувати двохетапне хірургічне лікування МО з використанням ВШБ як першого етапу.

\section{матеріали і методи дослідження}

Протягом 2011 - 2018 рр. на клінічній базі кафедри загальної хірургії №2 Університету обстежено та проліковано 97 пацієнтів з МО, а саме з суперожирінням та високим операційно-анестезіологічним ризиком (III - IV клас за шкалою ASA PS).

Хворих лікували в два етапи. Як перший етап 60 хворим встановлювали ВШБ на 6 міс (основна група), 37 хворим проводили консервативну терапію впродовж 6 міс, яка включала дієту, фізичну активність та поведінкове консультування (контрольна група). До основної групи включили пацієнтів, у яких не було протипоказань до встановлення ВШБ та які були згодні на застосування такого лікування; до контрольної - пацієнтів, у яких були протипоказання до встановлення ВШБ або які відмовлялися від такого лікування.

Протипоказаннями до встановлення ВШБ є грижі стравохідного отвору діафрагми значних розмірів, наявність аритмії, стійкої до фармакотерапії, вагітність, наркотична та алкогольна залежність, цироз печінки з варикозно розширеними венами стравоходу, виражені порушення психіки.

Як другий етап хворим обох груп проводили хірургічне лікування МО.

Співвідношення пацієнтів за статтю (чоловіки : жінки) в основній і контрольній групах було таким: 28 (46,7\%) : 32 (53,3\%) та 17 (45,9\%) : 20 (54,1\%) відповідно. В основній групі середній вік пацієнтів становив $(48,93 \pm 8,28)$ року (від 32 до 62 років), у контрольній - (49,3 49,72$)$ року (від 30 до 64 років). Середній IMТ дорівнював $(68,3 \pm 7,38)$ кг/ м $^{2}$ (від 53,55 до 77,81 кг/м²) - в основній групі та $(67,72 \pm$

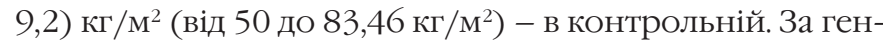
дерними, віковими та показниками клініко-інструментальних досліджень, які аналізували, обидві групи хворих не мали статистично значущої різниці (р > 0,05), тобто були порівнянні.
Для оцінки ефективності лікування хворих з МО аналізували показники IMT у динаміці, \% EWL, який розраховували за формулою: \%EWL = втрачена маса тіла (кг)/надлишкова маса тіла (кг) × 100. Якщо \%EWL був менше 20, лікування, яке застосовували на першому етапі, розцінювали як неефективне, якщо \%EWL дорівнював або перевищував 20 - як ефективне [8 - 10].

Операційно-анестезіологічний ризик оцінювали за шкалою ASA PS з урахуванням фізичного стану хворих, їх працездатності, ступеня вираженості наявної патологiii [11].

Період спостереження для всіх пацієнтів на першому етапі становив 6 міс, на другому - 12 міс. Між першим та другим етапами минало від 1 до 14 діб [12, 13].

У хворих основної групи використовували ВШБ

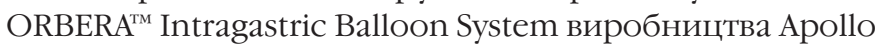
Endosurgery, Inc. Цей пристрій раніше був відомий як BioEnterics Intragastric Balloon ${ }^{\circledR}$ (BIB) компанії BioEnterics Corporation (BEC) [14]. Наповнювали балон фізіологічним розчином у кількості 700 мл з додаванням барвника метиленового синього. Балон залишався у шлунку 6 міс.

Комплекс консервативної терапії у пацієнтів контрольної групи включав дієтотерапію, фізичну активність та поведінкове консультування.

Згідно з керівництвом програми CINDI щодо харчування та рекомендаціями ВООЗ, МОЗ України застосовували гіпокалорійну збалансовану дієту, необхідну калорійність котрої розраховували за формулою: загальні енергетичні витрати (ккал/день) - 500 ккал/день $[15,16]$.

Фізичну активність призначали з урахуванням рекомендацій American College of Sports Medicine 2007 р. для схуднення та підтримки маси тіла. Починали з фізичної активності аеробного спрямування низької та середньої інтенсивності протягом 150 хв на тиждень та збільшували іiі до 250 хв [17]. Із форм фізичної реабілітації застосовували дозовану ходьбу, яка здійснювалась інтервальним методом з урахуванням рекомендацій National Institutes of Health, National Heart, Lung and Blood Institute 2006 p. [18].

Структурована поведінкова програма включала такі компоненти: самоконтроль з веденням харчових щоденників і записів діяльності пацієнта; контроль або модифікація тригерів з боку навколишнього середовища, котрі можуть запускати процес прийому їжі; сповільнення процесу вживання їжі; вживання страв та харчових продуктів лише за обіднім столом; постановку реальних цілей; навчання правильному харчуванню та його планування; Соціальну підтримку; розробку стратегій споживання їжі в умовах ресторану, вечірки тощо [19].

Лікарських засобів, тобто фармакологічних методів лікування самого ожиріння (орлістат тощо), у пацієнтів з МО, включених у дослідження, не використовували. Водночас приділяли необхідну увагу фармакотерапевтичному лікуванню наявних коморбідних станів індивідуалізовано у кожного пацієнта згідно з рекомендаціями ендокринолога, кардіолога, пульмонолога, ортопеда, інших фахівців.

Лапароскопічне шунтування шлунка (ЛШШ) - Rouxen-Y Gastric Bypass здійснювали за методикою FobiCapella [20]. Під час виконання лапароскопічної рукавної резекції шлунка (ЛРРШ) після мобілізації великої кри- 
визни шлунка відсікали шлунок до кута Гіса за допомогою зшиваючого апарата ECHELON FLEX 60 мм, відступивши від зонда 34 Fr на 1 см. При лапароскопічному регульованому бандажуванні шлунка (ЛРБШ) використовували бандаж «LAP-BAND $®$ System Surgical Aid in the Treatment of Obesity» виробництва Allergan (зараз - Apollo Endosurgery) за загальноприйнятою методикою.

Статистичну обробку результатів досліджень здійснювали за допомогою програми IBM SPSS Statistics Base v. 22.

\section{Результати та іх обговорення}

Проведено порівняльний аналіз динаміки показників маси тіла, IMT, \%EWL, операційно-анестезіологічного ризику на першому етапі лікування у хворих з МО основної та контрольної груп (табл. 1).

Через 6 міс лікування у пацієнтів основної групи спостерігали статистично значуще зменшення маси тіла та IMT. Фактична втрата маси тіла в середньому становила $(28,92 \pm 10,08)$ кг (максимальна - 52 кг, мінімальна - 17 кг). Через 6 міс лікування у пацієнтів контрольної групи не відбулося статистично значущого зменшення маси тіла та IMT. Фактична втрата маси тіла в середньому становила $(9,94 \pm 3,3)$ кг (максимальна - 19 кг), а у 13 хворих збільшилась початкова маса тіла. Середній \%EWL у хворих основної групи становив 22,69 \pm 5,87 та статистично значуще ( $<$ 0,001) перевищував зазначений показник у хворих контрольної групи. Принципово, що рівень операційно-анестезіологічного ризику за ASA PS у хворих основної групи статистично значуще ( $<$ < 0,001$)$ знизився, що уможливило проведення саме цим пацієнтам другого етапу лікування МО. В контрольній групі рівень опе- раційно-анестезіологічного ризику за ASA PS мав лише тенденцію до зниження, зміни були статистично незначущі ( $>$ 0,05). Саме у пацієнтів, котрим встановили ВШБ, суттєво зменшився клас операційно-анестезіологічного ризику - до 2,15 \pm 0,36 порівняно з 3,14 \pm 0,54 у пацієнтів, які отримували консервативну терапію (p < 0,001).

Отже, порівняльний аналіз динаміки відповідних показників хворих з МО та високим операційно-анестезіологічним ризиком основної та контрольної груп дає підстави для висновку про необхідність використання ВШБ як етапу підготовки до операції.

За показниками \%EWL судили про ефективність лікування хворих з МО основної та контрольної груп. Якщо показники \%EWL були менші 20, лікування вважали неефективним, дорівнювали або перевищували 20 - ефективним. В основній групі у 41 (68,33\%) хворого застосування ВШБ виявилося ефективним за даним критерієм, у контрольній групі консервативна терапія була ефективною лише у 1 (2,7\%) хворого.

Для вибору типу баріатричної операції на другому етапі лікування ми розробили алгоритм на базі аналізу механізмів основної патогенетичної дії різних оперативних втручань: рестриктивних, шунтуючих, комбінованих. Якщо показники \%EWL дорівнюють або перевищують 20, перевагу слід надавати рестриктивним баріатричним операціям; менше 20 - шунтуючому баріатричному втручанню; за наявності у пацієнта з МО цд 2-го типу незалежно від показників \%EWL перевага має бути надана шунтуючому баріатричному втручанню.

На підставі запропонованого нами алгоритму хворих розподілили на другому етапі лікування перед виконан-

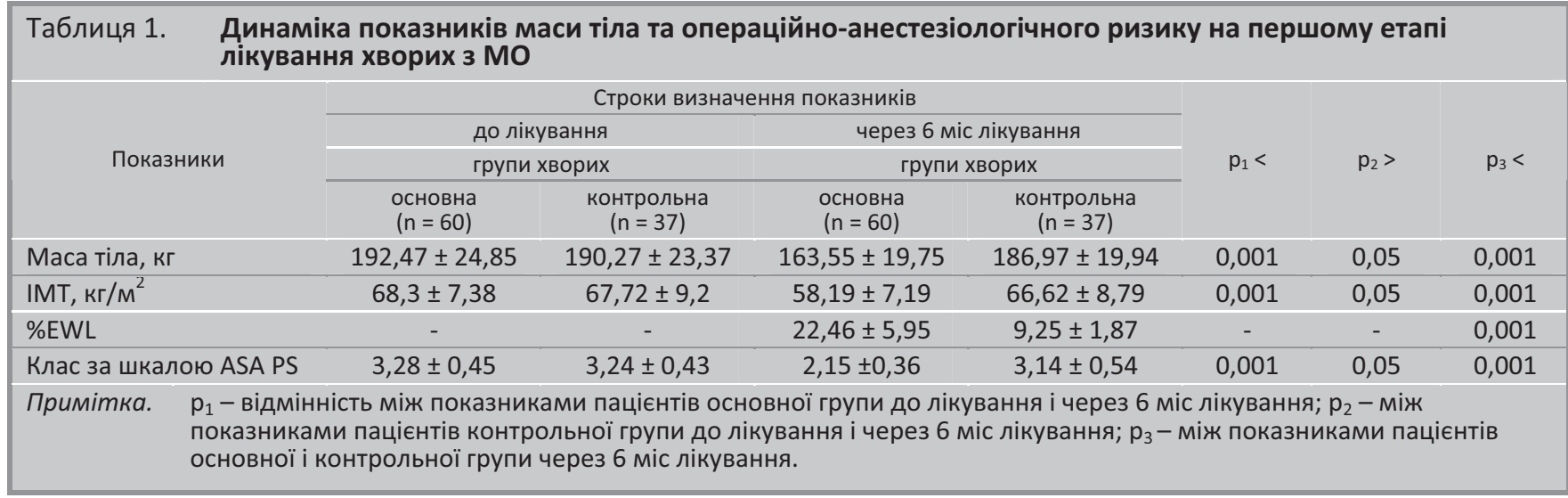

\begin{tabular}{|c|c|c|c|c|c|c|c|c|c|c|}
\hline \multirow{6}{*}{$\begin{array}{l}\text { Оперативні } \\
\text { втручання }\end{array}$} & \multicolumn{10}{|c|}{$\begin{array}{l}\text { Розподіл хворих на другому етапі перед виконанням баріатричної операції в залежності від } \\
\text { ефективності першого етапу лікування, наявності ЦД 2-го типу та вибору типу баріатричної } \\
\text { операції }\end{array}$} \\
\hline & \multicolumn{8}{|c|}{ Показник \%EWL } & \multirow{4}{*}{\multicolumn{2}{|c|}{ Разом }} \\
\hline & \multirow{2}{*}{\multicolumn{4}{|c|}{$\begin{array}{c}\text { дорівнюють або перевищують } 20 \text { (n=42) } \\
\text { цД 2-го типу }\end{array}$}} & \multirow{2}{*}{\multicolumn{4}{|c|}{ менше 20 (n=19) }} & & \\
\hline & & & & & & & & & & \\
\hline & \multicolumn{2}{|c|}{$\epsilon$} & \multicolumn{2}{|c|}{ немає } & \multicolumn{2}{|c|}{$\epsilon$} & \multicolumn{2}{|c|}{ немає } & & \\
\hline & абс. & $\%$ & абс. & $\%$ & абс. & $\%$ & абс. & $\%$ & абс. & $\%$ \\
\hline лшш & 32 & 62,8 & - & - & 12 & 23,5 & 7 & 13,7 & 51 & 83,6 \\
\hline ЛРРШ & - & - & 1 & 1,6 & - & - & - & - & 1 & 1,6 \\
\hline ЛРБШ & - & - & 9 & 14,8 & - & - & - & - & 9 & 14,8 \\
\hline Всього ... & 32 & 62,8 & 10 & 16,4 & 12 & 23,5 & 7 & 13,7 & 61 & 100 \\
\hline
\end{tabular}


ням баріатричної операції (табл. 2). У цілому на другий етап лікування визначили 61 пацієнта: 60 - основної групи та лише 1 - контрольної. Таким чином, другий етап лікування виявився можливим практично лише для хворих основної групи, оскільки використання консервативної терапії у переважної більшості хворих контрольної групи було недостатнім для зменшення початково високого ступеня операційно-анестезіологічного ризику.

Враховуючи поширеність ЦД 2-го типу серед хворих з МО та отримані результати використання ВШБ за критерієм \%EWL, серед баріатричних втручань перевагу надавали ЛшШ (у 83,6\% пацієнтів).

Проаналізована динаміка показників маси тіла, IMT, \%EWL у пацієнтів на другому етапі лікування до виконання баріатричної операції, обраної на підставі розробленого нами алгоритму, та через 12 міс. Маса тіла в середньому зменшилася $3(162,84 \pm 20,36)$ до $(108,28 \pm 14,11)$ кг (р < 0,001), середній IMT - $3(58,02 \pm 7,25)$ до $(38,53 \pm 4,45)$ кг $\mathrm{M}^{2}(\mathrm{p}<0,001)$, \% EWL у середньому становив 55,27 \pm 7,62. Фактична маса тіла в середньому зменшилася на $(54,56 \pm$ 10,9) кг (від 25 до 66 кг). У кінці повного курсу двохетапного лікування у хворих маса тіла зменшилася в середньому на $(83,31 \pm 16,15)$ кг (мінімально - на 43 кг, максимально - на 113 кг), \%EWL становив у середньому 65,28 \pm 6,65 (мінімальний - 53,61, максимальний - 80,49).

\section{Висновки}

1. У лікуванні МО, яке є актуальною медико-соціальною проблемою охорони здоров'я, провідна роль належить сучасним можливостям баріатричної хірургії. Виконання баріатричних операцій у переважної більшості хворих 3 MO, особливо суперожирінням, $є$ неможливим через високий операційно-анестезіологічний ризик.

2. Обгрунтована доцільність двохетапного лікування хворих з МО та високим операційно-анестезіологічним ризиком: перший етап - встановлення ВШБ, другий - виконання баріатричної операції.

3. Застосування ВШБ впродовж 6 міс приводить до зниження початково високого операційно-анестезіологічного ризику за шкалою ASA PS (p < 0,001) та зменшення маси тіла - \%EWL становить у середньому 22,46 \pm 5,95.

4. Якщо шляхом застосування ВШБ досягнуто показників \%EWL, які дорівнюють або перевищують 20, перевагу слід надавати рестриктивним баріатричним операціям; менше 20 - шунтуючому баріатричному втручанню; за наявності у пацієнта з МО цд 2-го типу, незалежно від показників \%EWL, перевага має бути надана шунтуючому баріатричному втручанню.

5. Запропоноване двохетапне лікування хворих з МО приводить до зменшення початкової маси тіла: \%EWL становив у середньому 65,28 \pm 6,65 (мінімальний - 53,61, максимальний - 80,49).

\section{References}

1. Obesity and overweight [Internet]. World Health Organization. 2017 [cited 2 February 2018]. Available from: http://www.who.int/news-room/ fact-sheets/detail/obesity-and-overweight.

2. Overweight and obesity [Internet]. World Health Organization. 2017 [cited 2 February 2018]. Available from: http://www.who.int/gho/ncd/ risk_factors/overweight_obesity/obesity_adults/en/
3. Body Mass Index | BMI Calculator - Severe Obesity Treatment [Internet]. International Federation for the Surgery of Obesity and Metabolic Disorders. 2018 [cited 2 February 2018]. Available from: http://www. ifso.com/body-mass-index/

4. Logue J, Thompson L, Romanes F, Wilson D, Thompson J, Sattar N. Management of obesity: summary of SIGN guideline. BMJ. 2010;340(2):154. doi: 10.1136/bmj.c154.

5. Stroh C, Birk D, Flade-Kuthe R, Frenken M, Herbig B, Höhne S, et al. Studie zur Qualitätskontrolle der operativen Therapie der Adipositas - Ergebnisse der Jahre 2005 und 2006. Zentralblatt für Chirurgie. 2008;133(5):473-8. doi: 10.1055/s-2008-1077002.

6. Mechanick J, Youdim A, Jones D, Garvey W, Hurley D, McMahon M, et al. Clinical practice guidelines for the perioperative nutritional, metabolic, and nonsurgical support of the bariatric surgery patient-2013 update. Obesity. 2013;21(1):1-27. doi: 10.1002/oby.20461.

7. Sedov V, Fishman M. Laparoskopicheskaya hirurgiya ozhireniya: Prakticheskoe rukovodstvo. Sankt Peterburg; 2009. 192 s. [In Russian].

8. Ribeiro da Silva J, Proença L, Rodrigues A, Pinho R, Ponte A, Rodrigues J et al. Intragastric Balloon for Obesity Treatment: Safety, Tolerance, and Efficacy. GE - Portuguese Journal of Gastroenterology. 2017. doi: $10.1159 / 000485428$.

9. Kotzampassi K, Grosomanidis V, Papakostas P, Penna S, Eleftheriadis E. 500 Intragastric Balloons: What Happens 5 Years Thereafter? Obesity Surgery. 2012;22(6):896-903. doi: 10.1007/s11695-012-0607-2.

10. Ali M, Moustarah F, Kim J. American Society for Metabolic and Bariatric Surgery position statement on intragastric balloon therapy endorsed by the Society of American Gastrointestinal and Endoscopic Surgeons. Surgery for Obesity and Related Diseases. 2016;12(3):462 7. doi: 10.1016/j.soard.2015.12.026.

11. ASA Physical Status Classification System - American Society of Anesthesiologists (ASA) [Internet]. Asahq.org. 2018 [cited 1 May 2018]. Available from: https://www.asahq.org/resources/clinical-information/ asa-physical-status-classification-system.

12. Ioffe O, Molnar I, Tsyura Y, Tarasyuk T, Stetsenko O, Kryvopustov M, et al. Vibir optimalnih strokiv vikonannya radikalnih bariatrichnih operatsiy pislya vidalennya vnutrishnoshlunkovogo balonu. Visnyk Ukrainskoi medychnoi stomatolohichnoi akademii «Aktualni problemy suchasnoi medytsyny.» 2017;59(3):115-8. [In Ukrainian].

13. Joffe O, Molnar I, Tarasyuk T, Tsyura Y, Stetsenko O, Kryvopustov M. Morphological changes of gastric mucosa after insertion of intragastric balloon. Klin Khir. 2015;(10):70-2. [In Ukrainian].

14. ORBERA ${ }^{\mathrm{TM}}$ Intragastric Balloon System (ORBERA ${ }^{\mathrm{TM}}$ ) Patient Information Booklet [Internet]. 2015 [cited 2 February 2018]. Available from: http://www.accessdata.fda.gov/cdrh_docs/pdf14/P140008a.pdf

15. World Health Organization. CINDI dietary guide [Internet]. Apps.who. int. 2018 [cited 1 May 2018]. Available from: http://apps.who.int/iris/ handle/10665/108342

16. Metodychni rekomendatsii z pryvodu konsultuvannia patsiientiv shchodo osnovnykh zasad zdorovoho kharchuvannia (zghidno z nakazom MOZ Ukrainy \# 16 vid 14.01.2013 r.). Mizhnarodnyi endokrynolohichnyi zhurnal [Internet]. 2013 [cited 1 May 2018];53(5):138-147. Available from: http://nbuv.gov.ua/UJRN/Mezh_2013_5_23 [In Ukrainian].

17. Physical Activity and Public Health: Updated Recommendation for Adults From the American College of Sports Medicine and the American Heart Association. Circulation. 2007;116(9):1081-93. doi: 10.1161/ CIRCULATION.107.185649.

18. U.S. Dept. of Health and Human Services, National Institutes of Health, National Heart, Lung, and Blood Institute. Your Guide To Physical Activity and Your Heart [Internet]. Nhlbi.nih.gov. 2006 [cited 1 May 2018]. Available from: https://www.nhlbi.nih.gov/files/docs/public/heart/phy active.pdf

19. Jensen M, Ryan D, Apovian C, Ard J, Comuzzie A, Donato K, et al. 2013 AHA/ACC/TOS Guideline for the Management of Overweight and Obesity in Adults. Circulation. 2013;129(25):102-38. doi: 10.1161/01. cir.0000437739.71477.ee

20. Ioffe O, Tsiura Iu, Stetsenko O, Tarasiuk T, Kryvopustov M. Laparoskopichne shuntuvannya shlunka yak operatsiya viboru u hvorih pri morbidnomu ozhirinni ta suputnomu metabolichnomu sindromi. Klin Khir. 2013;(11):17-20. [In Ukrainian]. 